\title{
Flypaper Effect Revisited: Evidence for Tax Collection Efficiency in Brazilian Municipalities
}

\author{
Enlinson Mattos * \\ Fabiana Rocha ** \\ Paulo Arvate ${ }^{\star \star \star}$
}

\begin{abstract}
Resumo
O objetivo do artigo é propor uma reinterpretação do tradicional efeito flypaper, fenômeno que ocorre quando as transferências do governo central para os governos locais aumentam o gasto público mais do que aumentos na renda privada. Aqui as transferências mais altas podem induzir menor eficiência na coleta de impostos do que os aumentos na renda. Inicialmente construímos um modelo que aponta a possibilidade de existência de efeito flypaper no contexto de um modelo de maximização padrão por parte dos governos locais. Depois construímos scores de eficiência para os municípios brasileiros usando Free Disposable Hull (FDH), levando em consideração dois produtos: a quantidade de impostos per capita coletados localmente - receita tributária - e o tamanho da economia informal - base tributária. Finalmente, usando mínimos quadrados dois estágios e regressões Tobit, em que o instrumento é construído a partir das regras de cálculo das transferências não condicionais estabelecidas na Constituição de 1988, e onde encontramos evidência de que as transferências têm o efeito oposto (negativo) ao da renda sobre a eficiência na taxação, chegou-se à reinterpretação do efeito flypaper.
\end{abstract}

\section{Palavras-Chave}

efeito flypaper, eficiência, coleta de impostos

\begin{abstract}
The purpose of this article is to propose a reinterpretation of the traditional flypaper effect according to which central government transfers to local governments increase public spending by more than do increases in private income. Here, higher transfers from the federal government might induce less efficiency in local tax collection opposed to the income effect. Initially, we build a model in order to point out the possible existence of that flypaper effect in a context of standard maximization on the part of local governments. Next, we construct efficiency scores for Brazilian municipalities using Free Disposable Hull (FDH), taking into consideration two outputs: amount of per capita local tax collected -tax revenue- and the size of local informal economy - tax base. Last, using two stages least squares and Tobit regressions, which the instruments is built upon the rules established in the 1988 Brazilian Constitution and where we find that unconditional transfer funds to municipalities, we estimate that transfers have the opposite effect (negative) of consumer's income on efficiency of taxation, which leads us to a reinterpretation of the flypaper effect.
\end{abstract}

\section{Keywords}

flypaper effect, efficiency, tax collection

\section{JEL Classification}

$\mathrm{H} 2 \mathrm{O}, \mathrm{H} 21, \mathrm{C} 67, \mathrm{C} 14$

* Artigo recebido em março de 2010 e aceito para publicação em março de 2011.

* Professor Adjunto da Escola de Economia de São Paulo/CEPESP - Fundação Getúlio Vargas - Endereço para contato: Rua Itapeva, 474 Bela Vista- São Paulo - CEP: 01332-000 - Email: enlinson.mattos@ fgv.br

* Professora Titular do Departamento de Economia - Universidade de São Paulo - Endereço para contato: Av. Prof. Luciano Gualberto,908 - Cid. Universitária - São Paulo - CEP: 05508-010 - E:mail: frocha@usp.br

*** Professor Doutor Escola de Administração de Empresas - Fundação Getúlio Vargas - Endereço para contato: Av. Nove de Julho 2029 - Bela Vista - São Paulo - CEP 01313-902 - E-mail: paulo.arvate@fgv.br 


\section{Introduction}

The difference between effects of consumer's incomes and intergovernmental transfers on public expenditure, the flypaper effect, is extensive ((HINES and THALER (1995)), however the literature has dedicated modest attention to the response of subnational governments in terms of tax collection. An exception is Hamilton (1986), who demonstrates that the deadweight loss from taxation can be a possible cause of the empirically observed flypaper effect.

Nevertheless, efficiency in tax collection is particularly relevant in a context of fiscal federalism. Given the vertical imbalances, local governments receive transfers from higher levels of the government in order to match their revenues and spending ((EICHENGREEN and VON HAGEN (1996)). These transfers enable local governments to provide the same level of public services while reducing the tax burden on local voters. However, they may also decrease the efficiency of tax collection due to their direct impact on the allocation of resources used to collect tax (defined as inputs) and their direct impact on tax revenue and tax base (output).

The purpose of this paper is to investigate the effect of intergovernmental transfers as compared to consumer's income (flypaper effect) on the efficiency of tax collection for 3,335 Brazilian municipalities in 2004. In order to do so we initially extend Hamilton's model by allowing for a tax collection function as a mechanism to gather tax revenue. The model points out the possible existence of the flypaper effect in a context of standard maximization on the part of local governments, which reinforces that its magnitude is an empirical dispute.

Next, we construct relative efficiency scores in tax collection for each municipality. It is possible to rank the (relative) efficiency of tax collection comparing the fiscal performance of each municipality with a tax frontier. We take into consideration two outputs and two inputs. In terms of output, we measure revenue collection by the amount of per capita local tax collected and the availability of tax base by the proportion of workers in the local formal economy. As inputs, we use per capita capital investments accumulated and depreciated by the rate of 3\% and the number of workers in direct or indirect local public administration divided by the population. Finally, we establish the relationship between the efficiency scores, transfers and income.

In order to deal with the problem of the endogeneity of transfers, we build an instrument for intergovernmental transfers from the rules used to transfer unconditional funds among municipalities established in the Brazilian Constitution. Consistently with Becker's (1996) argument that the flypaper effect is nothing 
but an econometric artifact (there is no "fiscal illusion"), we also test alternative specifications in order to avoid possible misspecification biases.

The results suggest that federal transfers to municipalities negatively affect the efficiency scores while consumer's income has the opposite effect. This leads to a reinterpretation of the traditional flypaper effect, which establishes that elevates in transfers increase public spending more than do increases in private income. According to our results, higher transfers from the federal government might in fact induce less efficiency in local tax collection as compared to increases in private income.

The paper is organized into four sections, being the first of it this introduction; the second section lays out a simple model that restates the flypaper effect in terms of efficiency of taxation, and not in terms of expenditure levels; the third section presents the empirical implementation. It introduces the estimation methodology, provides the rationale for the construction of the instrumental variable, and presents the data and the results for the relative efficiency scores; the fourth section discusses the empirical estimates of the flypaper effect and presents the decomposition of the flypaper effect on tax collection units, inputs and outputs; the fifth section concludes this paper.

\section{The Flypaper Effect Revisited - A Simple Model}

This paper recognizes that intergovernmental transfers are determined through a political process and that grant receipts are an outcome of the underlying preferences of the elected representatives. The bargaining process can be formally reduced to two stages. First, there exists a "federal budgetary stage" which determines how to distribute an exogenous budget across municipalities. The second stage considers the intergovernmental grant as given, and it consists in allocating these federal grants and private income between public and private consumption. Since the first stage is the political process which is being instrumented in our setup and which is described below, we only discuss here that the correlation between preferences for the public good and grant receipts can be positive, which invalidates the direct use of these transfers in the regression analyses. Those transfers might be correlated with unobservable political variables ((BARON and FEREJOHN (1987, 1989), PEREIRA (1996), GROSSMAN (1994), KNIGHT (2002)).

For the second stage, we extend Hamilton (1986) by accommodating a tax collection function in the local tax revenues. The author presents a simple model of optimal tax theory that focuses on the deadweight loss from taxation as the possible 
cause of the flypaper effect and postulates that grants allow for lower local taxes. This extension seems a reasonable strategy because the main assumption here is that only local taxation is distortionary, and that it is this effect that local pressure groups attempt to circumvent. At this point, it is necessary to define the concept of relative efficiency.

Definition 1: A local government is defined as relatively efficient if either there is no other local government that uses the same amount of (or less) input to produce more outputs or that produces the same amount of (or more) outputs with less use of inputs. Otherwise, that local government is considered inefficient and the degree of efficiency $(\varphi)$ is calculated by taking into consideration the output distance between the efficient and inefficient unity.

Formally, consider an economy with a composite good (x), a locally provided public service $(\mathrm{G})$, and a representative agent. ${ }^{1}$

The representative agent maximizes the following utility function:

$$
U(x, G)
$$

Following Hamilton (1986), we assume that local taxes are distortionary.

The individual's budget constraint can be written as:

$$
y \geq x+g(T)
$$

where $y$ is real income and $\mathrm{g}(\mathrm{T})$ represents the shadow cost of local taxes in terms of private consumption with the following properties: i) $g(0)=0$, ii) $g^{\prime}(T)>1$, and iii) $g^{\prime \prime}(T)>0$ if $\mathrm{T}>0 .^{2}$

The government's budget constraint contains two sources of revenues, $\mathrm{T}$, which is the revenue from local taxes and $t$, an intergovernmental grant. The budget constraint is, therefore,

$$
T+t \geq G
$$

1 If we assume a majority voting process for determining public good (G), the outcome of this process reflects the demand of the median voter $\left(\mathrm{G}^{\mathrm{m}}\right)$. With slight modification in the model, one can obtain the same results.

2 The deadweight loss of local taxation increases at an increasing rate. Note that grants from higher levels of government are assumed to be nondistortionary. 
We also assume that the household utility function is smooth and strongly quasiconcave, which is increasing in both of its arguments $(\mathrm{y}-\mathrm{g}(\mathrm{T})$ and $\mathrm{T}+\mathrm{t})$. After substituting for both constraints, we can rewrite the utility function of the household as:

$$
U=U(y-g(T), T+t)
$$

It should be mentioned that the government aims at maximizing the utility function of the representative household and that its choice variable is $\mathrm{T}$, which allows characterizing the solution of the local government as:

$$
-U_{1} g(T)+U_{2}=0
$$

A formal statement of the flypaper effect is that the marginal public expenditure due to a grant $(d G / d t=1+d T / d t)$ is greater than the marginal public expenditure arising from an equivalent increase in total community income $(d G / d y=d T / d y)$.

We assume that the amount of taxes collected is a function of the inputs used to that end. Specifically, that depends on how much capital (K) and labor (L) is employed to collect revenues for the government and how efficient these resources are put together $(\varphi)$ :

$$
T_{i}=f\left(K_{i}, L_{i}, \phi_{i}\right)
$$

Where $\mathrm{i}=1, \ldots, \mathrm{n}$ corresponds to the number of municipalities in Brazil and $\phi_{i}$ is a parameter that captures how efficient these inputs are combined to collect revenues.

Consider the total differentiation (omitting the subscripts on $\mathrm{K}$ and $\mathrm{L}$ ),

$$
\left[f_{\phi} d \phi_{i}+f_{k} d K+f_{L} d L\right]=d T_{i}
$$

Equation (7) reveals that in order to compensate for an increase in local taxes, the municipalities can i) increase efficiency $\left(f_{\phi} d \phi_{i}\right)$ or ii) increase the capital or labor level, which is the size of the local government whose objective is to collect tax revenue ([ $\left.\left.f_{K} d K+f_{L} d L\right]\right)$. The government's size to collect tax revenue (capital and labor) depends on the municipalities' choice regarding the allocation of resources to tax collection. For instance, it could be the case that local governments suffer pressures from specific groups whose aim is to obtain exemptions (elderly, poor, etc). To attain that claim, local governments can reduce the number of workers 
allocated to auditing, or to decrease investments that can help in the tax collection such as electronic tax payment system and record which connects their database with their counterparts in different spheres of the government.

To consider the partial effect of a change in the amount of transfer $(t)$, and the amount of own income (y), on the efficiency scores, totally differentiate Equation (5) and use Equation (7) to obtain:

$$
\begin{aligned}
& \frac{d \phi_{i}}{d t}=\frac{U_{12} g^{\prime}-U_{22}}{\left[U_{11} g^{\prime 2}-U_{1} g^{\prime \prime}-2 U_{12} g^{\prime}+U_{22}\right] f_{\phi} \phi} \\
& \frac{d \phi_{i}}{d y}=\frac{U_{11} g^{\prime}-U_{12}}{\left[U_{11} g^{\prime 2}-U_{1} g^{\prime \prime}-2 U_{12} g^{\prime}+U_{22}\right] f_{\phi} \phi}
\end{aligned}
$$

The "revisited flypaper effect" on the efficiency score is the result of:

$$
\frac{d \phi_{i}}{d t}-\frac{d \phi_{i}}{d y}=\frac{\left(U_{12} g^{\prime}-U_{22}\right)-\left(U_{11} g^{\prime}-U_{12}\right)}{\left[U_{11} g^{\prime 2}-U_{1} g^{\prime \prime}-2 U_{12} g^{\prime}+U_{22}\right] f_{\phi} \phi}
$$

which is the difference between the transfer effect and the income effect on the efficiency of tax collection. The denominator of Equation (10) is negative since it is the second derivative of the government's maximization condition using its correspondent budget constraint and the term $f_{\phi} \phi$ is positive. Therefore, the final effect can be positive or negative depending on the relative sign of $\left(U_{12} g^{\prime}-U_{22}\right)$ and $\left(U_{11} g^{\prime}-U_{12}\right)$. In order to have a negative flypaper effect on efficiency scores, that is, Equation (10) lower than zero, a sufficient condition is $\left(U_{12} g^{\prime}-U_{22}\right)-\left(U_{11} g^{\prime}-U_{12}\right)>0$. Since the second term of the numerator $\left(U_{11} g^{\prime}-U_{12}\right)$ is negative, once it is assumed that the public good is normal ( $\mathrm{dG} / \mathrm{dy}>0$ ) (leads Equation (9) to be positive), this is equivalent to having either a positive or low negative value for the term $\left(U_{12} g^{\prime}-U_{22}\right)$. In particular, a sufficient condition can be written as $\left|\left(U_{12} g^{\prime}-U_{22}\right)\right|<\left|\left(U_{11} g^{\prime}-U_{12}\right)\right|^{3}$

This means a lower effect, in absolute terms, on efficiency scores of grants than that one caused by income variation. This is what we label new flypaper effect, that

3 Note that this is not a necessary condition once one could obtain a similar negative flypaper effect by having a positive but large $\left(\mathrm{U}_{12}-\mathrm{U}_{22}\right)$. 
is, the difference in the effect of transfers on tax collection efficiency compared to the standard effect of transfers on spending.

\section{Empirical Implementation}

\subsection{Setting the Empirical Procedure}

The empirical procedure involves two stages:

The goal of the first stage is to construct a tax frontier. It is similar to a production frontier in the firm's problem of producing output where the government's output is taxes. In other terms, the idea is to measure the "wastefulness" of taxation.

As observed by Alfirman (2003), the difference between the fiscal frontier and current taxation cannot be considered strictly as a measure of inefficiency, representing in fact the level of unused tax potential. Given that the existence of unused tax potential may also be caused by the preference of municipalities' residents (they voluntarily prefer a low provision of public goods and services), inefficiency is only part of the story. We totally agree with this argument, but since we cannot determine the sources of the level of unused tax potential, we will treat the whole thing as coming from inefficiency.

In a frontier framework it is possible to rank the efficiency of tax collection by comparing the fiscal performance of each municipality with a tax frontier (fiscal potential). Along with the tax frontier, the highest possible level of output (revenue collection) is observed for a given level of input. Conversely, it is possible to determine the lowest level of input necessary to attain a given level of output. This way, it is possible to identify inefficient procedures in terms of input efficiency and in terms of output efficiency. The goal of the second stage is to identify the variables correlated with the inefficiency scores. ${ }^{4}$ More precisely, we try to determine which characteristics of the municipalities explain the high degree of heterogeneity observed in the scores.

The following tax collection efficiency function is estimated:

$$
\text { EffScore }_{i}=\beta_{o}+\beta_{1} \text { Transfers }_{i}+\beta_{2} \text { Income }_{i}+\gamma \text { Controls }_{+} \varepsilon_{i}
$$

4 The second stage uses output oriented scores as the dependent variables. The results do not change much if we use the input oriented scores instead. 
where Effscore $_{i}$ corresponds to the computed efficiency score for municipality i., Transfers $_{i}$ is our variable of interest and measures the amount of transfers received by municipality i., Income $e_{i}$ is the per capita income of that municipality, and Controls $_{i}$ represents a vector of other exogenous variables that are believed to explain the technology or preferences involved in determining (relative) efficiency.

The local government, however, may have incentives to collect less revenue from its own sources in order to receive higher transfers, or at least it can be less efficient in tax collection if that action can imply higher grant receipts. This is a typical endogeneity problem in econometrics and we attempt to solve it by building an instrumental variable. This variable must be correlated with tax collection efficiency only through the instrumented variable, and not with the residuals. This identification strategy is also attractive because of the possible selection on "unobservables", i.e., a municipality may be receiving a specific amount of transfers due to political power and groups of interest which are not observed by the researcher. The construction of the instrument aims to eliminate these biases.

\subsection{The Instrumental Variable}

The Brazilian municipalities can decide upon fines, exemptions and tax rates on two specific taxes in Brazil: the service tax (ISS) and the residential property tax (IPTU). Another source of revenues is the intergovernmental transfers that could come from the state and federal spheres.

Brazilian municipalities in fact depend heavily on transfers as a source of revenues. According to the Government Finance Statistics Yearbook, IMF, 2003, tax revenues average only $24 \%$ of total revenue for Brazilian municipalities. This large share of transfers received by Brazilian municipal governments led Shah (1994, p. 42) to argue that

"municipal governments in Brazil (...) should be the envy of all [local] governments in developing, as well as in industrial countries".

Most of intergovernmental transfers to Brazilian municipalities come from the Municipal Participation Fund (Fundo de Participação dos Municípios - FPM), currently composed of $23.5 \%$ of the net (gross minus deductions) amount collected 
through the federal income tax and a federal tax on industrialized products (consumer tax). In general terms, the MPF has two formulas to supply funds. First, it is related to state capitals and countryside. Considering that the New Constitution (1988) preserved the law number 5172 (1966), the MPF resources go 10\% to the state capitals, $86.4 \%$ to the countryside municipalities and the remainder is shared among the countryside municipalities with more than 142,633 inhabitants. The coefficient of each state capital is determined through the product of two factors: a population factor (coefficients from 2 to 5 ) and a per capita income factor (coefficients from 0.4 to 2.5). The first factor considers the share of the population of a specific capital city compared to the sum of the population of all capital cities. The larger the population share of the capital city, the larger the factor. When the population share is $4.5 \%$ or higher, the population factor is set to 5 . Accordingly, the per capita factor is the inverse of the fraction between municipalities' per capita income and Brazil's per capita income, in percentage terms. This number can go as high as $2.5 \%$. For the countryside municipalities, there is a fixed coefficient depending on population and the State in which the city is located. For those countryside municipalities with more than 142,633 inhabitants there is still $3.6 \%$ of the MPF to be divided according to similar criteria established for state capitals. The rest of residuals is distributed according to a formula established in 1989 (Complementary Law number 62) that takes into consideration the population (0.6 to 4 - from less than 10,188 habitants to more than 156,216 habitants).

The actual transfer of resources from one sphere of government to another, however, is the result of either political dissatisfaction with the current rule of distribution or take into account the change in the variables used in the redistribution criteria over time. Since the level of population and per capita income are adjusted annually for Brazilian municipalities, the coefficients of redistribution among municipalities adjust as well. ${ }^{5}$

The problem is that these two variables (population and per capita income) can be correlated with unobservable variables, and as a consequence, with the decision of tax collection. In particular, if the change in these two variables implies a decrease in the transfers received by a particular municipality, it can claim an attenuation of its loss. Depending on its political status, it can obtain a different formula for adjustment.

Therefore, a municipality whose population decreased (increased) does not necessarily have its participation in the transfer funds automatically decreased (increased)

5 There are several changes in the Brazilian legislation concerning redistribution. For instance, the Law 5172 of 1966, then the Decree Law number 1881 of 1981, followed by the Complementary Law number 91 of 1997. 
proportionally. There is an ongoing process of bargain based on the municipality's political status after which attenuation coefficients are applied. After that, municipalities can still complain and negotiate their redistributive grants until 30 days after the final publication of those data. Last, even municipalities with similar population and income per capita might have different coefficients because they belong to different states. Given that the "rules" used to transfer resources from the states and central government to the municipalities change constantly, these different rules render the use of unconditional transfers as instrument endogenous. ${ }^{6}$

This way it is necessary to find an instrumental variable that is associated with tax collection efficiency only through transfer, but not caused by the efficiency in tax collection, and that still captures unobservable effects.

We use the coefficients established in the rule of transfers described above to build our instrument. This way, we have a different distribution of transfers from the one generated by the rule in place in 2004, which allows us to eliminate the contemporaneous bias. Two reasons justify this as a valid instrument: i) The rule of distribution was legally defined, and so is definitely exogenous; ${ }^{7}$ ii) The rule of distribution was initially established several years ago and has been changed often, as discussed before. Therefore, it is reasonable to assume that the stock effect has been reduced. ${ }^{8}$

The instrument is built as follows. First, we collect data on federal government revenues that come mostly from two taxes in 2004: income tax and a tax on in-

6 Becker (1996) uses the amount of unconditional transfers to each unit as an instrument for total grants. Knight (2002) chooses one instrument based on the political power of congressional delegations to account for the exogenous part of grants variation related to highway spending in the U.S. However, his strategy has some drawbacks. In particular, if delegates typically serve in committees according to their preferences, this may not be exogenous to highway spending. A second instrument is the proportion of state representatives in the majority party. Given that the majority party is the same during a long period of time, this is clearly a variable that captures preferences of the voters in the state. In any case, the F-test for the instrumental variable is very low and the instrumental variables have different signs depending on whether they are measured at the House or at the Senate level. Gordon (2004) applies the underlying change in the data used as criteria to transfer grants as instrument to identify the causal effect of intergovernmental transfers. In particular, she uses the updated data given in 1990 census, which in turn leads to a discontinuous change in the grants distributed across municipalities. To some extent, her identification strategy resembles the one used in this paper. The census-determined change in grants from 1980 to 1990 can be instrumented by the change in the number of children and poor children in each district in that period. However, the use of updated variables is problematic when the updating process is known beforehand. The consequences in terms of grant payments can be taken into consideration on the part of the communities. This reduces the statistical advantages of a sharp discontinuity in the data as discussed in the paper.

7 For instance, Blundell, Duncan and Meghir (1998) use tax reform in the U.S. as an exogenous instrument for marginal tax variation among individuals. See also Hausman and Poterba (1987) for a discussion on this topic.

8 The correlation between the predicted distribution of transfers among Brazilian municipalities in 2004 and the one predicted in 2005 is -0.009 . 
dustrialized products; next, we multiply this amount by $22.5 \%$ to find the amount to be distributed to the municipalities in $2004 ;{ }^{9}$ last, we multiply the resulting amount by the individual coefficients explained above to obtain the specific amount of transfers to each municipality. This amount corresponds to the instrument for transfer and we label it Transfers from Rule (TFR).

\subsection{Data and Efficiency Scores}

In order to calculate the efficiency scores, we use two inputs defined as capital and labor. ${ }^{10}$ Per capita capital investments from 1980 to 2004 accumulated and depreciated by the rate of $3 \%$ are used as a proxy for capital $(\mathrm{K}) \cdot{ }^{11,12}$ Labor is calculated using the number of workers in direct or indirect local public administration divided by the population in 2004 .

The outputs are the amount of tax collected per capita and proportion of formal workers in the local economy. We dispute that the objective of tax administrator is not restricted to tax collection, and that it should also include availability of tax bases. There is a cost related to determination of tax base as well as policies that can tax these bases. The reduction of informal workers might decrease auditing costs. If the local governments only want to increase taxes, they can do so by imposing higher tax rates on those that already pay taxes. However, these individuals might have an incentive to misreport income/wealth/transactions after this increase in taxes since they already pay enough taxes, which in turn raises the auditing costs. Eventually, this policy could even cause future electoral loss on the incumbents. A much more efficient alternative would be to design a policy where everyone pays taxes with a smaller tax rate. Given that the tax rates would be lower, given tax revenues the local government would have less auditing costs what could be welfare-enhancing. ${ }^{13}$

9 Constitutional Reform n. 55/07 increased the amount transferred in $1 \%$ what makes the original amount $22.5 \%$.

10 In a previous version of this paper, total municipal expenditures per capita are also used as input. The results are available upon request.

11 We have tested alternative rates of depreciation ( $5 \%$ and $8 \%$ ), and the results were similar.

12 There is a distinction between formal (CLT) and informal workers in Brazil. The informal workers do not have the legal right of job tenure. We could say that their job tenure is more precarious than that of formal workers. The expression 'CLT' has its origin in Law 5452 of May of 1943, entitled the Consolidation of Labor Laws (CLT in Portuguese). This law establishes the rules of labor relations in the private sector. The data used to build the variable tax collection was taken from Ipeadata (2004). The variable that captures informality (inf) is taken from the CENSUS (2000), for instance, see Bajada (2002) and Giles and Caragata (1998).

13 Similar arguments are presented in Souza, Araujo and Tannuri-Pianto (2009) which uses the production and updating of taxpayer cadastres as output, i.e., the quantity of dwellings and unbuilt land that are registered in the cadastre of the IPTU plus the number of firms and individual taxpayers registered in the cadastre of the ISSQN. 
These variables allow us to calculate input and output relative efficiency scores whose range goes from 0 to 1 . Every municipality on the production possibility frontier receives the maximum score 1 . For instance, the input efficiency score indicates how much less input a municipality can use to obtain the same level of output of the efficient municipality. Similarly, the output efficiency score indicates how much more output could be produced (if the municipality were in the production frontier) given the level of its inputs.

This paper employs Free Disposable Hull (FDH) methodology. ${ }^{14}$ In public sector applications, particularly the evaluation of local government efficiency, most studies use nonparametric techniques such as Data Envelopment Analysis (DEA) or Free Disposable Hull (FDH).

For instance, from the spending side, Gupta and Verhoeven (2001) use FDH to evaluate the efficiency of public spending on education and health for 37 African countries. Afonso, Schuknecht and Tanzi (2005) analyze the public efficiency of OCDE countries also using FDH. Sousa, Cribari-Neto and Stosic (2005) apply a DEA approach to measure expenditure efficiency of Brazilian municipalities.

On the other hand, from the revenue side, Thirtle et al. (2000) use DEA to measure tax efficiency in 15 Indian states. Forund et al. (2005) evaluate the performance of local taxes offices of Norway using DEA. Barros (2007) analyses the technical and allocative efficiency of tax offices in Lisbon also using DEA, while Katharaki and Tsakas (2010) do the same for Greek tax offices. Sousa, Araújo and Tannuri-Pianto (2009) use DEA and FDH to calculate efficiency taxation scores for Brazilian municipalities.

The major advantage of FDH is that it imposes only weak assumptions on the production technology but still allows for comparison of efficiency levels among producers. The production set is not necessarily convex. That guarantees the existence of a continuous FDH which is going to be used as a dependent variable to identify the best practices in government tax collection, that is, to assess what determines (relative) efficiency. Besides, this methodology allows the detection of the most obvious cases of inefficiency since for each municipality classified as inefficient at least another municipality with better performance can be found in the sample.

$14 \mathrm{FDH}$ and DEA are nonparametric techniques of efficiency measurement. Another alternative is parametric and is denominated stochastic frontier regression (see, for example, GREENE (2003)). Alfirman (2003) estimates the tax potential of two sources of revenue for Indonesian local governments (local taxes and property tax), the stochastic frontier approach for Brazil; Ribeiro (1998) estimates the tax collection effort of Brazilian states estimating a stochastic frontier. 
There are, however, some drawbacks. First, is the possibility of efficiency by default, that is, the labeling of a municipality as efficient simply because there are not enough similar municipalities for comparison. Therefore, the ranking of efficiency reflects a lack of information that would allow adequate comparisons instead of effective superiority. Second, is the presence of outliers. Several approaches are available to deal with this problem, for example, descriptive methods (WILSON $(1993,1995))$ and the order-m approach (SIMAR (2003)). However, they require that the data be handled in great extent manually what is complicated given the great number of municipalities that must be analyzed. Besides, given the output complexity and the different environmental conditions faced by municipalities, the possibility of biased estimates of the frontier still remains.

We claim that by using such structure, it is possible to exclude the tax price effect on tax collection determinants. Suppose that we want to find out the determinants of tax collection in two different municipalities. One of them spends twice as much on tax collection activities as the other. If the two municipalities are similar in their characteristics, we expect to have the double amount of revenue collected in the municipality whose expenditure in tax collection is higher. That unit can audit more; can spend more money in training the auditors etc. We must take into consideration the cost/effort to collect tax in the municipalities in order to compute the determinants of tax collection. The cost to collect tax is the price paid to generate tax revenue and availability of tax base. By using the FDH methodology, we 'rank the municipalities' tax collection activity considering their input (price). The results are summarized in Table $2 .{ }^{15}$

15 We show the results on a state-by-state basis to allow more general conclusions. Results for each municipality are available upon request, as well as the complete estimates. 
Table 2 - Relative Efficiency Scores

\begin{tabular}{|c|c|c|c|c|c|c|c|}
\hline \multicolumn{2}{|c|}{$\begin{array}{l}\text { Sample (number of municipalities } \\
\text { within state) }\end{array}$} & $\begin{array}{l}\text { Input scores } \\
\text { proportion } \\
\text { of formal } \\
\text { workers -Tax } \\
\text { Base }\end{array}$ & $\begin{array}{l}\text { Output scores } \\
\text { proportion } \\
\text { of formal } \\
\text { workers -Tax } \\
\text { Base }\end{array}$ & $\begin{array}{c}\text { Input } \\
\text { scores-Tax } \\
\text { Revenue }\end{array}$ & $\begin{array}{c}\text { Output } \\
\text { scores-Tax } \\
\text { Revenue }\end{array}$ & $\begin{array}{l}\text { Input } \\
\text { scores } \\
\text { both }\end{array}$ & $\begin{array}{l}\text { Output } \\
\text { scores } \\
\text { both } \\
\text { outputs }\end{array}$ \\
\hline \multicolumn{8}{|l|}{ All Municipalities $(3,359)$} \\
\hline & Min & 0.017 & 0.010 & 0.017 & 0.000 & 0.017 & 0.015 \\
\hline & $\operatorname{Max}$ & 1.000 & 1.000 & 1.000 & 1.000 & 1.000 & 1.000 \\
\hline & Mean & 0.548 & 0.751 & 0.622 & 0.483 & 0.670 & 0.876 \\
\hline & Std & 0.073 & 0.619 & 0.346 & 0.363 & 0.349 & 0.668 \\
\hline Amapá(37) & Mean & 0,619 & 0,568 & 0,614 & 0,089 & 0,619 & 0,571 \\
\hline Acre (15) & Mean & 0,684 & 0,766 & 0,684 & 0,638 & 0,684 & 0,767 \\
\hline Amazonas (42) & Mean & 0,322 & 0,600 & 0,510 & 0,559 & 0,510 & 0,634 \\
\hline Roraima (9) & Mean & 0,480 & 0,655 & 0,319 & 0,220 & 0,482 & 0,658 \\
\hline Pará (22) & Mean & 0,635 & 0,769 & 0,631 & 0,564 & 0,648 & 0,775 \\
\hline Amapá (3) & Mean & 0,619 & 0,568 & 0,614 & 0,089 & 0,619 & 0,571 \\
\hline Tocantins (50) & Mean & 0,204 & 0,333 & 0,212 & 0,072 & 0,225 & 0,345 \\
\hline Maranhão (47) & Mean & 0,503 & 0,615 & 0,721 & 0,531 & 0,721 & 0,655 \\
\hline Piauí (85) & Mean & 0,442 & 0,478 & 0,548 & 0,260 & 0,548 & 0,529 \\
\hline Ceará (115) & Mean & 0,392 & 0,513 & 0,486 & 0,341 & 0,548 & 0,533 \\
\hline Rio Grande do Norte (93) & Mean & 0,445 & 0,665 & 0,536 & 0,417 & 0,539 & 0,678 \\
\hline Paraíba (105) & Mean & 0,373 & 0,570 & 0,407 & 0,183 & 0,424 & 0,572 \\
\hline Pernambuco (122) & Mean & 0,518 & 0,661 & 0,494 & 0,322 & 0,548 & 0,681 \\
\hline Alagoas (73) & Mean & 0,453 & 0,559 & 0,457 & 0,242 & 0,458 & 0,570 \\
\hline Sergipe (45) & Mean & 0,469 & 0,551 & 0,390 & 0,119 & 0,488 & 0,566 \\
\hline Bahia (154) & Mean & 0,574 & 0,672 & 0,621 & 0,465 & 0,624 & 0,688 \\
\hline Minas Gerais (503) & Mean & 0,558 & 0,731 & 0,522 & 0,335 & 0,605 & 0,756 \\
\hline Espírito Santo (58) & Mean & 0,474 & 0,754 & 0,480 & 0,346 & 0,578 & 0,783 \\
\hline Rio de Janeiro (62) & Mean & 0,749 & 0,886 & 0,821 & 0,719 & 0,870 & 0,939 \\
\hline São Paulo (460) & Mean & 0,592 & 0,856 & 0,802 & 0,714 & 0,820 & 0,915 \\
\hline Paraná (308) & Mean & 0,474 & 0,768 & 0,482 & 0,303 & 0,548 & 0,783 \\
\hline Santa Catarina (252) & Mean & 0,551 & 0,834 & 0,500 & 0,296 & 0,668 & 0,859 \\
\hline Rio Grande do Sul (388) & Mean & 0,654 & 0,852 & 0,566 & 0,409 & 0,696 & 0,868 \\
\hline Mato Grosso do Sul (69) & Mean & 0,333 & 0,609 & 0,512 & 0,269 & 0,515 & 0,628 \\
\hline Mato Grosso (72) & Mean & 0,314 & 0,623 & 0,408 & 0,280 & 0,418 & 0,647 \\
\hline Goiás (146) & Mean & 0,440 & 0,630 & 0,612 & 0,435 & 0,626 & 0,708 \\
\hline
\end{tabular}

The frontier results suggest a large number of efficient cities in the Southeast/ South of Brazil (São Paulo, Minas Gerais, Espírito Santo, Rio de Janeiro, Paraná, Santa Catarina and Rio Grande do Sul). Also, $82 \%$ of the states that have efficient 
cities include their capital city as one of them. The state of São Paulo, the richest and most developed one, has 25 cities classified as efficient, while Rio Grande do Sul has 18 and Santa Catarina 15. In most cases, when states of the Southeast/ South region have an efficient city, that one is the capital city, (approximately 70\%). Piauí, the poorest state in Brazil, has no efficient city while Maranhão, the second poorest, has two, and one of them is the capital city, São Luís.

The results also indicate that 95 municipalities present at least one type of efficiency (input or output for the three different outputs: tax collection, tax base or both). Almost 15\% (13 out of 95) are state capitals. Other municipalities such as Manacapuru (Amazonas), Rorainópolis (Roraima), Bacabal (Maranhão), Vila Velha (Espírito Santo) and São João de Miriti (Rio de Janeiro) are also efficient in all criteria.

The variables of interest are intergovernmental transfers to the municipalities and consumer's income. According to our theoretical model (Equation 10) it could be the case that the higher these transfers, the higher the level of inefficiency compared to the effect of consumer's income. A negative sign of transfers and/or an effect lower than the counterpart income effect would imply that municipalities are revenue-dependent on central and state government assistance. If this is the case, the central government should design a new transfer policy that would induce municipalities to increase efficiency and use all their tax potential, reducing this perverse flypaper effect to a minimum.

The control variables aim to capture specific characteristics of the municipalities such as technology, economic and social characteristics, and fiscal indicators. We also include the ideology of mayors and municipal groups of interest. ${ }^{16}$ The sources and descriptive statistics of the data are provided in the Appendix (Table Al and A2). ${ }^{17}$

16 A branch of the political economy literature aims to show that a group of citizens lobby for governmental actions to benefit their members (OLSON (1965), PELTZMAN (1976) and BECKER (1983)). The incorporation of political institutions into models of local government was performed primarily by Romer and Rosenthal (1980, 1982), Filimon, Romer, and Rosenthal (1982), Courant, Gramlich and Rubinfield (1979). These papers propose an agenda-setter model, where budget-maximizing bureaucrats set the agenda for local spending referenda. Voters usually choose a high level of spending due to the binary (high or low) menu of choices proposed by the bureaucrats.

17 The choice of these variables is uncontroversial and matches the empirical literature. For instance, see a survey on this topic in Bailey and Connolly (1998). We also created a dummy variable that captures whether a municipality has a high public debt according to the Fiscal Responsibility Law 2000 (LRF - Lei de Responsabilidade Fiscal). This variable is statistically insignificant. 


\section{Empirical Estimates of the Flypaper Effect}

\subsection{Results}

As observed before, the main problem with estimating Equation (11) concerns the endogeneity of the level of transfers received by each municipality. Municipalities with low revenue collection and low tax bases could receive a higher level of transfers from the central government, and have the incentives to do so.

In the first stage, we consider a regression of actual level of transfers in each municipality on the eligible transfers according to 1989 Complementary Law and all the controls. In the second stage, we use the predicted transfers for each municipality from the first stage as instrument for the actual transfers and consider the computed relative efficient scores as dependent variables.

Initially, we present the results for the first stage, that is, the one associated with the calculation of the instrument and evaluation of its adequacy. The instrument is significant and valid since its exclusion from the above regressions reduces dramatically the adjusted $\mathrm{R}^{2}$ (see Appendix - Table A3). ${ }^{18}$

\section{Table 3 - Instrumental Variable - First Stage}

\begin{tabular}{lc|c}
\hline \multirow{2}{*}{ Independent Variable } & \multicolumn{2}{c}{ Dependent Variable: Transfers } \\
\cline { 2 - 3 } & Linear & Logarithmic \\
Transfers from Rule (TFR) & $1.091^{\star * \star}$ & $0.397^{\star \star \star}$ \\
Observations & 25.03 & 0.038 \\
Adjusted R2 & 3335 & 3335 \\
\hline
\end{tabular}

Note: ${ }^{* *}$ Significant at $1 \%$ level. The standard error is italicized and control variables were omitted.

In the second stage we use the log of output-oriented FDH scores as dependent variables in a regression analysis in order to find the exogenous factors that affect municipalities' performances. Given that the efficiency scores assume values between zero and one, the ordinary least squares (OLS) estimator of the parameters will be inconsistent, that is, it will not converge on probability to the true unknown parameter. The use of the log of scores, however, will lead to unbiased OLS estimates as long as the scores only assume strictly positive values. Besides the OLS estimator will be inefficient, and

18 This two-step process is run simultaneously to avoid inconsistent estimates of the variance term. Observe that control variables are used in the first and second stage regressions. 
the problem worsens with the proportion of censored observations in the sample (see GREENE (1981)). Due to the small number of censored observations in the sample there is not much reason for concern. To deal with the problem of endogeneity we use OLS twice (two-stage least squares) as discussed before. Another reason for using the $\log$ of efficiency scores is due to Becker (1996). She argues that the choice of the model influences the significance of the traditional flypaper effect on expenditures, with the logarithmic specification reducing the significance of the flypaper effect. This way a logarithmic version would avoid the possible inflated bias on the flypaper estimates due to misspecification modeling. A Tobit model would also be used to deal with censored observations. Parameters are usually estimated by maximum likelihood (ML), and the assumptions of normality and homoskedasticity are required so that inconsistent parameter estimates are obtained. Several papers have used a two stage approach, where efficiency is estimated in the first stage and then the estimated efficiencies are regressed on exogenous covariates in the second stage. However, as pointed by Simar and Wilson (2007), non-parametric efficiency estimates are serially correlated what makes conventional methods (OLS and Tobit) inconsistent in the second stage regression. They suggest bootstrap procedures to deal with the problem. Since there is no consensus on the literature regarding the subject we estimate equation (12) using both 2SLS and Tobit: ${ }^{19}$

$$
\text { EffScore }_{i}=a^{\beta_{o}} \text { Transfers }_{i}^{\beta_{1}} \text { Income }^{\beta_{2}} \text { Controls }^{\gamma} \varepsilon_{i}
$$

Table 4 presents the logarithmic regression estimates using our instrumental variable for transfers. The first and second columns present the results when both tax revenue and availability of tax base are considered as outputs. The results for tax revenues and the availability of tax base taken separately as products are presented from the third to sixth columns. ${ }^{20,21}$

19 In fact we also run Simar and Wilson (2007) robust standard errors but considering only a two stages estimation procedure (ignoring the endogeneity of transfers). The results are similar and are available upon request.

20 The full estimates using Tobit are in Table A4 in the appendix. The full estimations using 2SLS are available upon request.

21 Note that we consider estimates instead of true efficiency measures. Since this strategy leads to an overestimation of the error variance, which tends not to reject the null hypothesis, this reinforces our results concerning the case when we do reject the null hypothesis. We also tried other control variables for each municipality such as poverty, number of doctors, latitude and longitude. Last, per capita public expenditure on administration was tried as an alternative input for the efficiency scores. The results are robust to these specifications. 
Table 4 - Flypaper Effect on Relative Efficiency Score

\begin{tabular}{|c|c|c|c|c|c|c|}
\hline \multirow[t]{2}{*}{ Independent Variables } & \multicolumn{2}{|c|}{ Both } & \multicolumn{2}{|c|}{$\begin{array}{l}\text { Standardized Tax Revenue } \\
\text { per capita }\end{array}$} & \multicolumn{2}{|c|}{$\begin{array}{c}\text { Standardized ratio Between } \\
\text { Formal and Informal Workers } \\
\text { - Tax Base }\end{array}$} \\
\hline & $2 S L S$ & Tobit & $2 S L S$ & Tobit & $2 S L S$ & Tobit \\
\hline \multirow[t]{2}{*}{ Transfers } & $-0.3832^{\star * *}$ & $-0.3705^{\star \star *}$ & 0.1326 & 0.1707 & $-0.497^{\star * \star}$ & $-0.4884^{\star \star *}$ \\
\hline & 0.0745 & 0.0800 & 0.1318 & 0.1419 & 0.0821 & 0.0850 \\
\hline \multirow[t]{2}{*}{ Income } & $0.5046^{\star \star \star}$ & $0.5415^{\star \star \star}$ & $-0.3035^{\star \star \star}$ & $0.9050^{\star \star \star}$ & $-0.3319^{\star *}$ & $0.5146^{\star \star \star}$ \\
\hline & 0.0411 & 0.0424 & 0.1117 & 0.0656 & 0.0849 & 0.0463 \\
\hline Controls & Yes & Yes & Yes & Yes & Yes & Yes \\
\hline Estimated Flypaper & $-0.8878^{\star \star *}$ & $-0.9120^{\star \star \star}$ & $0.4361^{*}$ & $-0.7349^{*}$ & $-0.1651^{*}$ & $-1,003^{\star * *}$ \\
\hline Observations & 3335 & 3335 & 3335 & 3335 & 3335 & 3,335 \\
\hline Wald Testfor Exogeneity & & $23.8^{\star * *}$ & & $2.36^{\star}$ & & $24.7^{\star * *}$ \\
\hline
\end{tabular}

Note: ${ }^{* * *},{ }^{* *},{ }^{*}$ significant at $1 \%, 5 \%$ and $10 \%$.

Standard errors in italics.

Equation (12) shows that the flypaper effect (revisited) on efficiency score in tax collection comes from the difference between consumer's income and transfer effects on those scores. If transfers induce lower efficiency response compared to consumer's income, the final result is negative.

Table 4 presents our main results. In particular, it shows that there is a negative and significant flypaper effect on tax collection efficiency for all specifications, except 2SLS when tax revenue is the only output. For instance, in column 1 the flypaper effect estimated implies a decrease in the efficiency of $-0.912=(-$ $0.3832)-(+0.5046))$. It is precisely estimated in five out of six specifications. The mean value of our estimated (and significant) flypaper effect is -0.75 . That is our reinterpretation of the flypaper effect, i.e., transfers reduce tax collection efficiency compared to income effect.

The only exception is given in column 3, where a positive flypaper effect is observed. ${ }^{22}$ That is possible in our model (see Equation 9), and a plausible explanation is that the marginal disutility of taxes could be large enough due to its distortion that an increase in transfers induce policies to reduce inefficiency in tax collection and, therefore, to decrease the marginal cost of public funds.

22 The literature on median voter preference could work as guide here. It could be the case that the variable income is capturing the effect of median voter preferences on the dependent variable. The richer is the median voter, less willing he/she would be to pay taxes what result in less implementation of effort on tax collection. That could happen because he/she needs less public funds, and therefore less efficiency in tax collection. 
Three points addressed by this paper deserve further attention in order to guarantee the robustness of the results. The first one is to calculate efficiency scores using Data Envelopment Analysis (DEA). The second one is to deal with the problem of outliers. The third one is to use as output tax revenue instead of tax revenue per capita. Sousa, Araújo e Tannuri-Pianto (2009) estimate DEA-CRS (DEA with constant returns to scale), DEA-VRS (DEA with variable returns to scale) and FDH in order to estimate residuals efficiency scores for 3438 Brazilian municipalities. They first compute robust efficiency score by combining bootstrap and jackknife resampling, and then regress the resulting efficiency scores on municipalities'characteristics. The residuals of the regressions (OLS and quantile) measure pure technical efficiency, that is, efficiency after accounting for exogenous factors.

Although their purpose is completely different from ours, their work tackles these three points and provides further evidence on the revisited flypaper effect (Table 5 ). The same evidence is obtained using quantile regressions which allow the impacts of the independent variables to be different across the distribution of tax efficiency scores. We also present in the last column of the Table 5 our correspondent result, i.e., we present our OLS estimation considering the log of our FDH efficiency scores. Although they are not fully comparable (our efficiency scores consider standardized per capita data), the flypaper effect can be observed in all of the estimations. Moreover, in all of them, the effect is significant. Actually our coefficient seems to be the lower bound among all the estimates available. ${ }^{23}$

\section{Table 5 - Determinants of Robust Efficiency Scores (OLS Regressions)}

\begin{tabular}{|c|c|c|c|c|}
\hline & DEA-CRS & DEA-VRS & $\mathrm{FDH}$ & $\mathrm{FDH}($ MRA $)$ \\
\hline Income per capita & $0.033^{\star \star \star}$ & $0.023^{\star \star \star}$ & 0.003 & $0.0004^{\star \star \star}$ \\
\hline Grants & $-0.619^{\star * *}$ & $-0.332^{* * *}$ & $-0.103^{\star \star}$ & $-0.0001^{* * *}$ \\
\hline Controls & Yes & Yes & Yes & Yes \\
\hline $\begin{array}{l}\text { Flypaper (significant) } \\
\text { according to our concept }\end{array}$ & $-0.652^{\star * *}$ & $-0.355^{* \star *}$ & $-0.106^{\star \star *}$ & $-0.0005^{\star * *}$ \\
\hline Number of Observations & 3242 & 3242 & 3242 & 3830 \\
\hline
\end{tabular}

***, **, ${ }^{*}$ significant at 1\%, 5\% and 10\%. Source: Sousa, Araújo, and Tannuri-Pianto (2009), Table 4, p. 18. Last column corresponds to our OLS estimates using the log of efficiency scores as the dependent variable.

23 Another restriction to our results concerns spatial aspects given that we do not take them into consideration. Although they might be very important, we understand that a theoretical model which motivates its inclusion would be necessary. As discussed in Brueckner (2003), including spatial effects only "to control for spatial interaction" can lead to biased estimation for all parameters, spatially related and others. Therefore, since we aim at testing our theoretical model, our results can be understood as conditional on the absence of spatial effects. Future work can be conducted to enhance such comprehensive effects in the flypaper effect. 


\subsection{Decomposing the Effect on Tax Collection Efficiency - SUR Analysis}

In order to determine the channel through which transfers are affecting the efficiency scores, we also estimated an equation for each of the outputs and inputs. We use the same parameter vector in all the equations. Since the disturbances in the different equations include at least one factor in common, given that the efficiency in tax collection implies that the output could be increased and/or the input could be decreased, we employ the seemingly unrelated regression model (SUR). The results are presented in Table 6:

Table 6: Seemingly Unrelated Regression

\begin{tabular}{|c|c|c|c|c|}
\hline & \multicolumn{4}{|c|}{ Linear Model } \\
\hline & \multicolumn{4}{|c|}{ Dependent Variables } \\
\hline & \multicolumn{2}{|c|}{ Output } & \multicolumn{2}{|c|}{ Input } \\
\hline & $\begin{array}{c}\text { Ratio between } \\
\text { Formal and Informal } \\
\text { Workers }\end{array}$ & $\begin{array}{l}\text { Tax Revenue } \\
\text { per capita }\end{array}$ & $\begin{array}{c}\text { Total Public } \\
\text { Employment per capita }\end{array}$ & Capital Stock per capita \\
\hline \multicolumn{5}{|l|}{$\begin{array}{l}\text { Independent } \\
\text { Variables }\end{array}$} \\
\hline \multirow[t]{2}{*}{ Transfers } & $-1.62 \mathrm{e}-06$ & 0.0001 & $1.40 \mathrm{e}-06^{\star *}$ & -6392.09 \\
\hline & $6.83 e-06$ & 0.003 & $7.35 \mathrm{e}-07$ & 11102.83 \\
\hline \multirow[t]{2}{*}{ Income } & $0.00023^{*}$ & $0.16^{*}$ & -0.00001 & -44248.76 \\
\hline & 0.0000725 & 0.042 & $7.81 \mathrm{e}-06$ & 117945.8 \\
\hline Observations & 3,005 & 3,005 & 3,005 & 3,005 \\
\hline \multirow[t]{5}{*}{$\mathrm{R}^{2}$} & 0.13 & 0.03 & 0.01 & 0.001 \\
\hline & \multicolumn{4}{|c|}{ Logarithmic Model } \\
\hline & \multicolumn{4}{|c|}{ Dependent Variables } \\
\hline & \multicolumn{2}{|c|}{ Output } & \multicolumn{2}{|c|}{ Input } \\
\hline & $\begin{array}{c}\text { Ratio between } \\
\text { Formal and Informal } \\
\text { Workers }\end{array}$ & $\begin{array}{l}\text { Tax Revenue } \\
\text { per capita }\end{array}$ & $\begin{array}{c}\text { Total Public } \\
\text { Employment per capita }\end{array}$ & Capital Stock per capita \\
\hline \multicolumn{5}{|l|}{$\begin{array}{l}\text { Independent } \\
\text { Variables }\end{array}$} \\
\hline \multirow[t]{2}{*}{ Transfers } & 0.011 & 0.083 & $0.054^{* *}$ & -0.102 \\
\hline & 0.035 & 0.053 & 0.026 & 0.071 \\
\hline \multirow[t]{2}{*}{ Income } & $0.235^{\star}$ & $0.640^{*}$ & $-0.059^{* *}$ & $0.309^{*}$ \\
\hline & 0.038 & 0.058 & 0.029 & 0.078 \\
\hline Observations & 2,996 & 2,996 & 2,996 & 2,996 \\
\hline $\mathrm{R}^{2}$ & 0.13 & 0.18 & 0.01 & 0.01 \\
\hline
\end{tabular}

Note: ${ }^{*},{ }^{* *}$ significant at $1 \%$ and $5 \%$ level, respectively. Standard-errors in italics. The equations include the same controls used before and are available upon request. 
The estimates in Table 6 indicate that income is important to explain positively the proportion of formal workers (output), the tax revenue per capita (output) and the capital stock per capita (input), but it affects negatively the total public employment (input). If the municipalities are richer (higher income per capita), then they have incentive to collect more tax revenues and to increase the proportion of formal workers. This might be the result of better policies used to audit tax collection or due to the decrease in the marginal cost of auditing, given that it is easier to observe wealthier individuals. The results of capital stock per capita suggest that once the municipalities earn more income, then they are able to spend more money on capital stock. However, the negative effect on total public employment per capita is surprising. One possible explanation is that as income increases, the private sector grows faster than its public counterpart, which decreases the participation of public workers in that local economy. Nevertheless, this result deserves further investigation in the future. Transfers, however, are important to explain positively only total public employment per capita (input), i.e, the higher the level of transfers, the more local governments tend to hire public workers. This result relates to the ones obtained by Arvate, Marconi, Moura and Palombo (2008), who have shown the appropriation on salaries in Brazilian states'governments.

These findings suggest that the economic response of the municipalities when there is an increase in money resources varies according to the nature of these resources. In particular, when exogenous money is in play, municipalities seem to appropriate it by hiring more public workers. If the increase in resources comes from wealthier consumers (income effect), then we observe an increase in outputs (formal workers and tax revenue) and a decrease in input (public workers). In other terms, the results in this paper suggest that intergovernmental transfer causes the (relative) inefficiency through excess of labor input while (consumer's) income effect plays in the direction of improving tax collection efficiency.

Last, it is important to mention that when tax revenue per capita is the dependent variable (column 2 in both linear and logarithmic models), then we have an empirical correspondence to the theoretical model proposed by Hamilton (1986). For the linear model, it is possible to see that the marginal effect of income (significant and positive) is one thousand times larger than transfer (which is not significant) to increase tax revenue.

\section{Concluding Remarks}

The purpose of this article is to propose a reinterpretation of the traditional flypaper effect according to which central government transfers to local governments 
increase public spending by more than do increases in private income. Here, higher transfers from the federal government might induce less efficiency in local tax collection opposed to the income effect.

We initially develop a simple theoretical model where the revisited flypaper effect is derived. We then try to verify if the theoretical result is empirically plausible, estimating the flypaper effect on tax collection efficiency for Brazilian municipalities in 2004. Initially we apply a nonparametric methodology (Free Disposable Hull- FDH) to construct efficiency scores in tax collection for each municipality, taking into consideration two outputs: amount of per capita local tax collected - tax revenue- and the size of local formal economy - tax base. This strategy eliminates the price effect of tax collection, since it captures its extension by taking into consideration the associated cost of tax imposition and/or auditing. After that we build an exogenous instrument for intergovernmental transfers from the rules defining the amount of unconditional funds that legally must be transferred to the municipalities. The aim of the instrument is to eliminate the endogenous characteristic of intergovernmental transfers due to political factors (VEIGA and PINHO (2007)).

Our results suggest that unconditional grants affect negatively the efficiency in tax collection as opposed to consumer's income, leading to a reinterpretation of the flypaper effect.

One lesson that comes from our results is that local governments in Brazil should seek additional revenues in their own resources. This does not mean though to implement some new taxes, but to exploit more efficiently the existing tax base.

If the result obtained here and the lesson that comes out of it is general enough, that is a question for further investigation. Following the traditional literature on the flypaper effect, grant receipts and taxes can only be equivalent resources theoretically, but we only know that if we look carefully at other fiscally decentralized economies.

\section{References}

AFONSO, A.; SCHUKNECHT, L; TANZI, V. 2005. Public sector efficiency: an international comparison, Public Choice, vol. 123, n. 3-4, June, p. 321-342.

ALFIRMAN, L. 2003. Estimating stochastic frontier tax potential: can Indonesian local governments increase tax revenues under decentralization? Working Paper 03-19. University of Colorado at Boulder. 
BAILEY. S.; CONNOLLY, S. 1998. The flypaper effect: identifying areas for further research. Public Choice, 95: 335-361.

BAJADA, C. 2002. How reliable are estimates of the underground economy? Economics Bulletin, vol. 3, no. 14, p. 1-11.

BARON, D.P.; FEREJOHN, J.A. 1987. Bargaining and agenda formation in legislatures. The American Economic Review, 77(2):303-309.

BARON, D.P.; FEREJOHN, J.A.1989. Bargaining in legislatures. American Political Science Review, 83 (4):1181-1206.

BARROS, C. P. 2007. Technical and allocative efficiency of tax offices: a case study, J. Public Sector Performance Management, 1, p. 41-60.

BECKER, E.1996. The illusion of fiscal illusion: Unsticking the flypaper effect. Public Choice, 86: 85-102.

BECKER, G. 1983. A theory of competition among pressure groups for political influence. Quarterly Journal of Economics, August: 371-400.

BLUNDELL, R.; DUNCAN, A.; MEGHIR, C.1998. Estimating labor supply responses using tax reforms, Econometrica, p. 243-249.

BRUECKNER, J. (2003). Strategic interaction among governments: an overview of theoretical studies. International Regional Science Review, 26, 175-188.

COURANT, P. N.; GRAMLICH E. M.; RUBINFIELD, D. 1979. The stimulative effects of intergovernmental grants, or Why Money sticks where it hits. In Fiscal federalism and grants-in-aid, Mieszkowski and Oakland (eds.), Washington Urban Institute.

EICHENGREEN, B.; VON HAGEN, J. 1996. Fiscal federalism and monetary union - is there a trade of between federalism and budgetary restrictions, NBER Working Paper 5517, Cambridge: Massachusetts.

FILIMON, R.; ROMER, T.; ROSENTHAL, H. 1982. Asymmetric information and agenda control. Journal of Public Economics, February: 51-70.

FØRSUND, F.R; KITTELSEN, S.; LINDSETH, F. 2005. Efficiency and productivity of Norwegian tax offices, Memorandum 29/2005, University of Oslo, Department of Economics.

GILES, D.E.; CARAGATA, P.J. 1998. The learning path of the hidden economy: tax and growth effects in New Zealand. Department of Economics, University of Victoria.

GORDON, N.2004. Do federal grants boost school spending? Evidence from Title I, Journal of Public Economics 88(9-10): 1771-92.

GREENE, W.H.1981. On the asymptotic bias of the ordinary least squares estimator of the Tobit model, Econometrica, 49, 505-513.

GREENE, W. H. 2003. Econometric Analysis, Prentice Hall, Fifth Edition. 
GROSSMAN, P.J. 1994. A political theory of intergovernmental grants. Public Choice, 78: 295-303.

GUPTA, S.; VERHOEVEN, M. 2001. The efficiency of government expenditures experiences from Africa. Journal of Policy Modeling, 23, 433-467.

HAUSMAN, J.; POTERBA, P. 1987. Household behavior and the tax reform act of 1986, Journal of Economic Perspectives, p. 101-119.

HAMILTON, J. H.1986. The flypaper effect and the deadweight loss from taxation. Journal of Urban Economics 19: 148-155.

HINES, J. R.; THALER, R.H.1995. Anomalies: the flypaper effect. Journal of Economic Perspectives 9 (4): 217-26.

IMF. 2003. Government Finance Statistics Yearbook.

IBGE. Instituto Brasileiro de Geografia e Estatística, Pesquisa de Informações Básicas Municipais, (http://www.ibge.gov.br).

IPEA. Instituto de Pesquisa e Economia Aplicada, Ministério do Planejamento.

(http://www.ipeadata.gov.br).

KATHARAKI, M.; TSAKAS, M. 2010. Assessing the efficiency and managing the performance of Greek tax offices. Journal of Advances in Management Research, vol. 7 , issue 1, p. 58-75.

KNIGHT, B. 2002. Endogenous federal grants and crowd-out of state government spending: theory and evidence from the Federal Highway Program. American Economic Review, vol. 92, 71-92.

OLSON, M. 1965. The logic of collective action. Cambridge, Massachusetts: Harvard University Press.

PELTZMAN, S. 1976. Toward a more general theory of regulation. Journal of Law and Economics, August: 211-48.

PEREIRA, P.T.C. 1996. A politico-economic approach to intergovernmental lumpsum grants. Public Choice, 88: 185-201.

RIBEIRO, E. P. 1998. Transferências intergovernamentais e esforço fiscal dos estados brasileiros. Anais do XXI Encontro Brasileiro de Econometria.

ROMER, T.; ROSENTHAL, H.1980. An institutional theory of the effect of intergovernmental grants. National Tax Journal, December: 451-58.

ROMER, T.; ROSENTHAL, H. 1982. Median voter or budget maximizers: evidence from school expenditure referenda. Economic Inquiry, October: 556-78.

SHAH, A.1994. The reform of intergovernmental fiscal relations in developing and emerging market economies. Washington: World Bank.

SIMAR, L. 2003. Detecting outliers in frontier models: a simple approach. Journal of Productivity Analysis, 20, 391-424. 
SIMAR, L.; WILSON, P.W. 2007. Estimation and inference in two-stage, semiparametric models of production process. Journal of Econometrics, vol. 136(1), p. 31-64.

SOUSA, M. da C. S.; CRIBARI-NETO, F.; STOSIC, B. 2005. Explaining DEA technical efficiency scores in an outlier corrected environment: the case of public service in Brazilian municipalities. Brazilian Review of Econometrics, number 2, p. 289-315.

SOUSA, M. da C.S.; ARAÚJO, P.; TANNURI-PIANTO, M.E. 2009. Residual and technical tax efficiency scores for Brazilian municipalities: a two-stage approach, Anais do XXXI Encontro Brasileiro de Econometria.

THIRTLE, C., B.; SHANKAR, P.; CHITKARA, S.; CHATTERJEE; MOHANTY. 2000. Size does Matter: technical and scale efficiency in Indian state jurisdictions. Review of Development Economics, 4, 340-352.

VEIGA, L.G.; PINHO, M.M. 2007. The political economy of intergovernmental grants: evidence from maturing democracy. Public Choice, published on line, August.

WILSON, P.1993. Detecting influential observations in deterministic non-parametric frontiers models with multiple outputs. Journal of Business and Economic Statistics, 19(3), p. 319-323.

WILSON, P.W. 1995. Detecting influential observations in Data Envelopment Analysis. Journal of Productivity Analysis, 6(1), p. 27-45. 


\section{Appendix}

\section{Table Al - Description of Variables}

\begin{tabular}{|c|c|c|}
\hline Description & Variable Name & Search \\
\hline $\begin{array}{l}\text { The per capita transfers from both state and local } \\
\text { governments. }\end{array}$ & Transfers & Ipeadata, 2004. \\
\hline The per capita income in the municipality. & Income & Ipeadata, 2004. \\
\hline $\begin{array}{l}\text { The parties classified as center-left and left are de- } \\
\text { nominated by the variable left and the parties from } \\
\text { center-right and right are denoted as right. Dummy } \\
\text { variable equals } 1 \text { for parties classified left (right) and } \\
\text { zero the otherwise. }\end{array}$ & $\begin{array}{l}\text { Mayor Party Right and } \\
\text { Mayor Party Left }\end{array}$ & $\begin{array}{l}\text { We use the ideological classification of } \\
\text { the mayors parties for } 2004 \text { (Pesquisa } \\
\text { de Informações Básicas Municipais of } \\
\text { the IBGE) following Coppedge (1997). }\end{array}$ \\
\hline $\begin{array}{l}\text { Dummy variable equals } 1 \text { whether the municipality } \\
\text { has the tax service data set computerized and zero } \\
\text { the otherwise. }\end{array}$ & $\begin{array}{l}\text { IPTU Computerized and } \\
\text { ISS Computerized }\end{array}$ & $\begin{array}{l}\text { Pesquisa de Informações Básicas } \\
\text { Municipais, IBGE, } 2004 .\end{array}$ \\
\hline $\begin{array}{l}\text { The percentage of people with more than sixty five } \\
\text { years in the municipality living alone. }\end{array}$ & Elderly & Ipeadata, 2000. \\
\hline $\begin{array}{l}\text { The percentage of urban population over resident } \\
\text { population in the municipality. }\end{array}$ & Urbanization & Ipeadata, 2000. \\
\hline The population density in the municipality & Density & Ipeadata, 2000. \\
\hline $\begin{array}{l}\text { The percentage of people in the municipality with } \\
\text { electric energy in their residence. }\end{array}$ & Power Electric & Ipeadata, 2000. \\
\hline $\begin{array}{l}\text { The percentage of residents in the municipality with a } \\
\text { computer in their residence. }\end{array}$ & Housing Computer & Ipeadata, 2000. \\
\hline $\begin{array}{l}\text { The Economically Active Population divided by the } \\
\text { Working Age Population. }\end{array}$ & Employment & Ipeadata, 2000. \\
\hline $\begin{array}{l}\text { The cost of transport of the Municipal Headquarters } \\
\text { until the nearest State Capital. }\end{array}$ & Transportation & Ipeadata, 1995. \\
\hline $\begin{array}{l}\text { The percentage of population in the municipality di- } \\
\text { vided by the state population. }\end{array}$ & Population & Ipeadata, 2000. \\
\hline
\end{tabular}




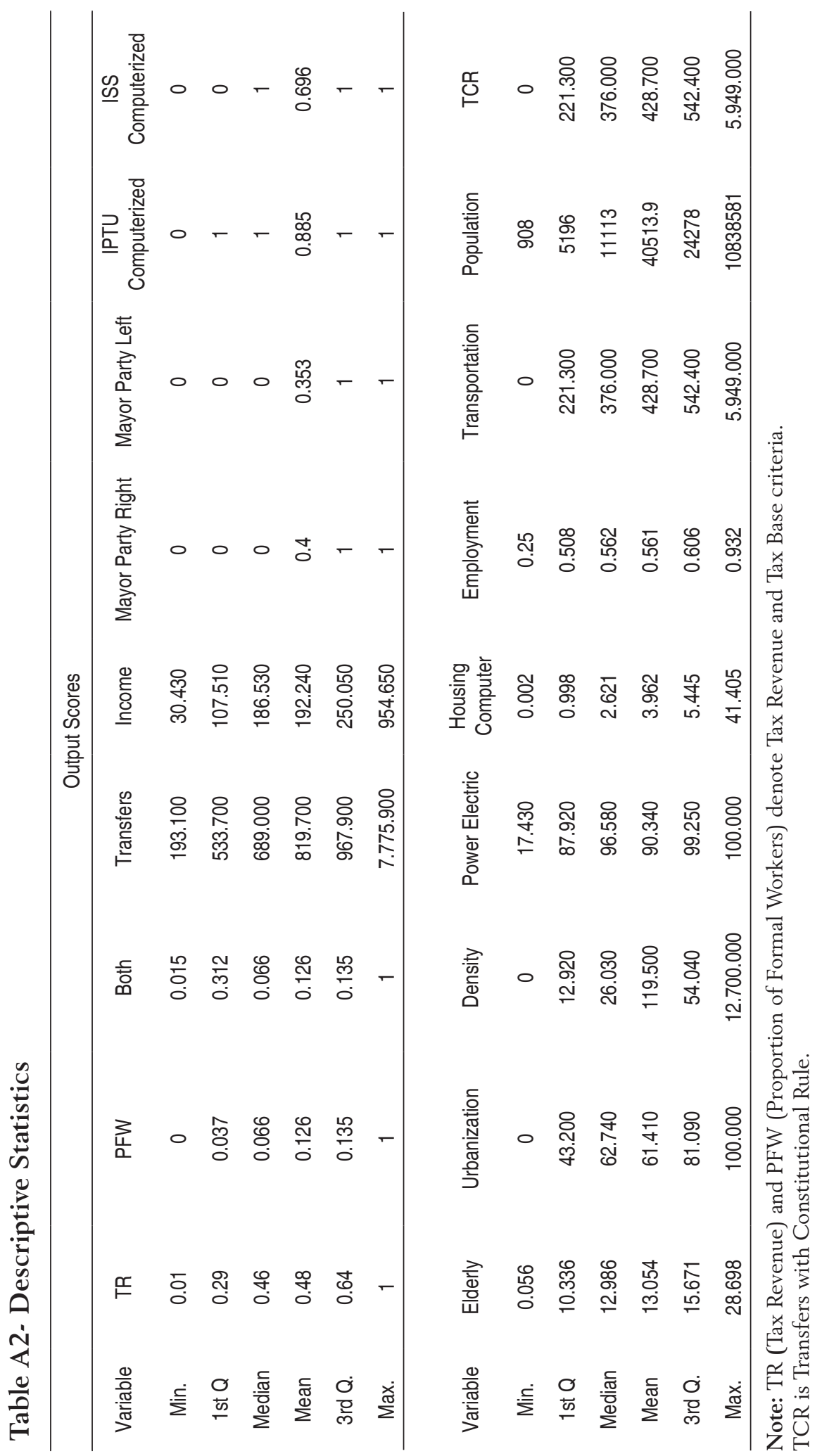

Est. Econ., São Paulo, 41(2): 239-267, abr.-jun. 2011 
Table A3- First Stage Regression

First Stage - Dependent Transf

\begin{tabular}{|c|c|c|}
\hline & Linear & Log \\
\hline \multirow[t]{2}{*}{ Transftab } & $1,091^{* * *}$ & $0.397^{* * *}$ \\
\hline & 25,033 & 0,038 \\
\hline \multirow[t]{2}{*}{ right } & $-23,858$ & $-0,018$ \\
\hline & 15,403 & 0,014 \\
\hline \multirow[t]{2}{*}{ left } & $-40.164^{* *}$ & 0,005 \\
\hline & 15,792 & 0,013 \\
\hline \multirow[t]{2}{*}{ iptuinform } & 8,850 & $-0.023^{*}$ \\
\hline & 21,531 & 0,013 \\
\hline \multirow[t]{2}{*}{ issinform } & $31.431^{* *}$ & $0.017^{*}$ \\
\hline & 15,775 & 0,011 \\
\hline \multirow[t]{2}{*}{ elderly } & 0,607 & $-0.036^{* \star *}$ \\
\hline & 1,597 & 0,012 \\
\hline \multirow[t]{2}{*}{ urb } & $-1.128^{* * *}$ & $-0.037^{\star * *}$ \\
\hline & 0,381 & 0,013 \\
\hline \multirow[t]{2}{*}{ density } & $-0.021^{*}$ & $-0.025^{\star \star *}$ \\
\hline & 0,012 & 0,006 \\
\hline \multirow[t]{2}{*}{ eletr } & $1.278^{* *}$ & 0,031 \\
\hline & 0,631 & 0,037 \\
\hline \multirow[t]{2}{*}{ compu } & $-6.645^{\star *}$ & $0.013^{*}$ \\
\hline & 3,273 & 0,007 \\
\hline \multirow[t]{2}{*}{ emp } & $-15,128$ & $-0.061^{*}$ \\
\hline & 90,463 & 0,034 \\
\hline \multirow[t]{2}{*}{ Income } & $1.153^{* * *}$ & $0.257^{* * *}$ \\
\hline & 0,149 & 0,020 \\
\hline \multirow[t]{2}{*}{ transp } & $0.062^{* * *}$ & $-0,005$ \\
\hline & 0,018 & 0,009 \\
\hline \multirow[t]{2}{*}{ pop } & $-0.00004^{*}$ & $-0.070^{\star \star \star}$ \\
\hline & 0,000 & 0,019 \\
\hline \multirow[t]{2}{*}{ _cons } & $145.68^{* *}$ & $6.605^{\star * \star}$ \\
\hline & 65,333 & 0,205 \\
\hline
\end{tabular}

***, ${ }^{* *},{ }^{*}$ significants at $1 \%, 5 \%$ and $10 \%$ respct

Adj R2

0,4598

0,602

Standard errors in italics.

Revenue and Base (I)

\begin{tabular}{lr}
\hline Linear & Log \\
\hline$-0,000090$ & $-0,000271$
\end{tabular}


Table A4- Regression Results

\begin{tabular}{|c|c|c|c|c|c|c|}
\hline \multirow[t]{2}{*}{ IV - Dep: } & \multicolumn{2}{|c|}{ Both Outputs } & \multicolumn{2}{|c|}{ Tax Revenue } & \multicolumn{2}{|c|}{ Propotion of Formal Workers } \\
\hline & $2 S L S$ & 2STobit & $2 S L S$ & 2STobit & $2 S L S$ & 2STobit \\
\hline & $\log$ & $\log$ & $\log$ & $\log$ & $\log$ & $\log$ \\
\hline \multirow[t]{2}{*}{ iransf } & $-0.3832^{\star * *}$ & $-0.3705^{\star * *}$ & 0,1326 & 0,1707 & $-0,497^{\star * *}$ & $-0.4884^{* * *}$ \\
\hline & 0,0745 & 0,0800 & 0,1318 & 0,1419 & 0,0821 & 0,0850 \\
\hline \multirow[t]{2}{*}{ right } & $-0,0118$ & $-0,0080$ & 0,0142 & 0,0202 & $-0,0044$ & $-0,0056$ \\
\hline & 0,0182 & 0,0183 & 0,0312 & 0,0313 & 0,0203 & 0,0204 \\
\hline \multirow[t]{2}{*}{ left } & $-0.0416^{* *}$ & $-0.0397^{\star *}$ & 0,0267 & 0,0305 & $-0,0401^{*}$ & $-0.0388^{*}$ \\
\hline & 0,0184 & 0,0188 & 0,0317 & 0,0319 & 0,0207 & 0,0207 \\
\hline \multirow[t]{2}{*}{ iptuinform } & 0,0344 & 0,0268 & $-0,0539$ & $-0,0694$ & 0,044 & 0,0345 \\
\hline & 0,0351 & 0,0350 & 0,0547 & 0,0537 & 0,038 & 0,0374 \\
\hline \multirow[t]{2}{*}{ issinform } & $0.0792^{* * *}$ & $0.0757^{* * *}$ & $0.0842^{* *}$ & $0.0779^{* *}$ & $0,0860^{* * *}$ & $0.0848^{* * *}$ \\
\hline & 0,0208 & 0,0206 & 0,0336 & 0,0337 & 0,0228 & 0,0228 \\
\hline \multirow[t]{2}{*}{ elderly } & $-0.0500^{* *}$ & $-0.0470^{* *}$ & $0.1312^{\star * *}$ & $0.1375^{\star * *}$ & $-0,0708^{* * *}$ & $-0,0698$ \\
\hline & 0,0214 & 0,0214 & 0,0350 & 0,0350 & 0,0234 & 0,0233 \\
\hline \multirow[t]{2}{*}{ urb } & $-0.1603^{* * *}$ & $-0.1710^{* * *}$ & $0.1072^{* * *}$ & $0.1068^{* * *}$ & $-0,1872^{* * *}$ & $-0.1879^{* * *}$ \\
\hline & 0,0253 & 0,0251 & 0,0396 & 0,0395 & 0,0269 & 0,0271 \\
\hline \multirow[t]{2}{*}{ density } & $0.0267^{* * *}$ & $0.0368^{* * *}$ & $-0,0167$ & $-0,0110$ & $0,0327^{\star * *}$ & $0.0346^{\star * *}$ \\
\hline & 0,0075 & 0,0078 & 0,0135 & 0,0138 & 0,008 & 0,0081 \\
\hline \multirow[t]{2}{*}{ eletr } & $0.4207^{\star \star *}$ & $0.3640^{* * y}$ & $-0.3466^{* * *}$ & $-0.3609^{* * *}$ & $0,5165^{\star \star \star}$ & $0.5041^{* * *}$ \\
\hline & 0,0840 & 0,0840 & 0,1180 & 0,1182 & 0,0911 & 0,0910 \\
\hline \multirow[t]{2}{*}{ compu } & $0.1296^{\star \star *}$ & $0.1273^{* * *}$ & 0,0268 & 0,0214 & $0,1354^{* * *}$ & $0.1376^{\star * *}$ \\
\hline & 0,0173 & 0,0172 & 0,0241 & 0,0241 & 0,0187 & 0,0185 \\
\hline \multirow[t]{2}{*}{ emp } & $-0.3085^{\star * *}$ & $-0.3410^{* * *}$ & $0.8931^{* * *}$ & $-0.3048^{* * *}$ & $0,5132^{* * *}$ & $-0.3443^{* * *}$ \\
\hline & 0,0773 & 0,0771 & 0,0639 & 0,1115 & 0,0459 & 0,0835 \\
\hline \multirow[t]{2}{*}{ Income } & $0.5046^{\star \star *}$ & $0.5415^{\star * *}$ & $-0.3035^{* * *}$ & $0.9050^{* * *}$ & $-0,3319^{* *}$ & $0.5146^{\star * *}$ \\
\hline & 0,0411 & 0,0424 & 0,1117 & 0,0656 & 0,0849 & 0,0463 \\
\hline \multirow[t]{2}{*}{ transp } & $-0.1032^{* \star *}$ & $-0.1093^{* * *}$ & $-0.1415^{\star * *}$ & $-0.1406^{* * *}$ & $-0,0972^{* * *}$ & $-0.0995^{\star * *}$ \\
\hline & 0,0110 & 0,0115 & 0,0207 & 0,0210 & 0,0118 & 0,0119 \\
\hline \multirow[t]{2}{*}{ pop } & $-0.0466^{* * *}$ & $-0.0353^{*}$ & $0.2807^{* * *}$ & $0.2980^{\star * *}$ & $-0,0668^{* * *}$ & $-0.0633^{* * *}$ \\
\hline & 0,0201 & 0,0217 & 0.0373 & 0,0403 & 0,0216 & 0,0226 \\
\hline \multirow[t]{2}{*}{ _cons } & $-1.4031^{* *}$ & $-1.4916^{* *}$ & $-9.2634^{* * *}$ & $-9.6888^{* * *}$ & $.0,9182$ & $-0,9473$ \\
\hline & 0,6993 & 0,7336 & 1,2398 & 1,3086 & 0,7691 & 0,7888 \\
\hline
\end{tabular}

${ }^{* *},{ }^{* *},{ }^{*}$ signific. at $1 \%, 5 \%$ and $10 \%$.

Standard errors in italics 